\title{
Quando o estudante é o objeto do estudo
}

\author{
Sergio Pedro Baldassin \\ Disciplina de Psicologia Médica e Psiquiatria, Faculdade de Medicina do ABC (FMABC) - Santo André (SP), Brasil. \\ E-mail: sergio.baldassin@fmabc.br
}

DOI: http://dx.doi.org/10.7322/abcshs.v39i3.659

O período de treinamento de um estudante universitário é desgastante e não raramente pode provocar - no início, durante ou especialmente no final do curso - um aumento de sintomas já instalados após alguns anos de cursinho pré-vestibular. Ou, ainda, pode gerar novos problemas que o estudante jamais acreditou que sofreria.

Para piorar, nem sempre a família, os amigos e a Instituição de Ensino estão preparados para detectar esses indícios e ajudar o discente. Desse modo, esta tarefa acaba, frequentemente, ficando para alguns professores. E há muito tempo reconhecemos que o equilíbrio psicoemocional do aluno é também um objetivo acadêmico que permite seu melhor aproveitamento, seja cognitivo ou psicomotor.

Além disso, o aluno encontra em seu novo ambiente os desafios de socializar-se com um grupo de pessoas que atingiram com sucesso o mesmo objetivo que ele. Isso pode ser perturbador.

Por outro lado, utilizar o estudante universitário para pesquisar não apenas características desta população é um fato frequente. Se forem alunos na área da saúde, a combinação não podia ser melhor, pois são interessados, curiosos, acessíveis aos pesquisadores que fazem parte da Docência e confiáveis pelo seu grau de esclarecimento e a obsessão pelo perfeccionismo.

Desta forma, neste fascículo da ABCS Health Sciences, três estudos ${ }^{1-3}$ destacam que esta população merecia ser comentada como uma parceira frequente dos pesquisadores no mundo. No primeiro artigo, Alves e Malafaia ${ }^{1}$, atentos a saúde e ao comportamento dos estudantes de uma universidade de Goiás, detectam que 68,3\% população estudada utiliza-se de automedicação, com destaque para analgésicos, antinflamatorios e antibióticos.

Por que será que estes estudantes não estão lidando de maneira mais saudável com sua própria saúde, a despeito de seus conhecimentos e da proximidade com especialistas? Estão cursando uma área da Saúde, mas suas fontes de orientação são, principalmente, seus pais, que em sua maioria possuía ensino fundamental incompleto, e de farmacêuticos comuns. Será que a instituição tem instrumentos para cuidar disso? Deveria. E agora tem este estudo para se guiar.

Embora com índices inferiores a outros estudos de outras regiões citados pelos autores, esta instituição (se não fosse pelos pesquisadores) poderia ter detectado este fato? Como a Instituição vai lidar com o achado? Eles vão entender a prioridade deste evento e instituir uma abordagem adequada? Este é o tipo de questionamento que, ao ler um artigo como este todos nós temos, ao imaginar o que faríamos e como terminarão o curso estes alunos. Poderemos ver estes alunos mais saudáveis graças ao trabalho destes dois pesquisadores? Estes autores, como muitos de nós, ao final escreveram quase que automaticamente: "mais estudos precisam ser realizados" ou "este estudo permitirá abordagens diferenciadas deste tipo desta população ou problema”. Quantos de nós publicamos os resultados depois destas frases anos depois?

Muitos medicamentos devem poder ser acessados sem burocracia, é claro, mas a população recebeu instrução adequada para saber utilizá-los? Ela tem acesso a especialistas, não importa se não é em uma região rica e urbana? Ela sabe dos riscos do conhecimento parcial?

Em nosso campus na FMABC, há três anos, resolvemos criar um "Checkup" Calouro e um Pronto Atendimento, que funciona diariamente, e alguns resultados positivos tem sido obtidos. O maior deles? Uma referência para buscar respostas de forma rápida e facilmente acessível - um grande segredo para evitar desvios de comportamento na atitude com a própria saúde.

Será realmente um exagero ter políticas e especialistas estudando como cuidar desta população da mesma maneira que eles são treinados para cuidar dos outros a vida toda?

Muito bem vindo, este trabalho, perturbadoramente simples, que esperamos que desperte olhares e atitudes.

No segundo artigo, Silva e colaboradores ${ }^{2}$ abordam outro tipo de paradoxo entre estudantes na área da Saúde: o fato de que eles também não estão protegidos do uso de substâncias psicoativas, a despeito do conhecimento que recebem e do seu treinamento observando o tratamento das dependências e dos abusos.

A população frequentemente fica chocada ao saber que um estudante ou profissional da área da Saúde é surpreendido abusando ou recebe tratamento por fazer uso destas. Existem, inclusive, momentos do curso e períodos na história onde autores encontram uso até maior nesta população quando comparados aos índices da população geral. Por que eles não estão mais protegidos? Até que ponto a 
instituição os ensinou sobre estes riscos? Será que devemos aceitar que eles têm a obrigação de servir de exemplo e de modelo usando a força de seu "caráter" e deveriam ser dispensados de receber cuidados como qualquer outro indivíduo ou até maior mediante sua falsa sensação de que são os que tratam e não os que são tratados?

O Conselho de Medicina de São Paulo, há muitos anos, já recebeu um grupo de especialistas que estuda este assunto e presta assistência, sob sigilo e técnica apurada, ajudando as Instituições, inclusive, a criar mecanismos de readaptação e abordagens legais justas e saudáveis. Mas para estudantes o número de serviços que prestam apoio ou atendimento ainda é pequeno e incerto, especialmente com a abertura de dezenas de escolas médicas (ao total, eram 241 em novembro de 2014).

Entretanto Silva et al. abordam um curso de Filosofia onde predomina uma população jovem, feminina, onde quase $70 \%$ já utilizou na vida uma substância psicoativa, incluindo álcool, tabaco, maconha.

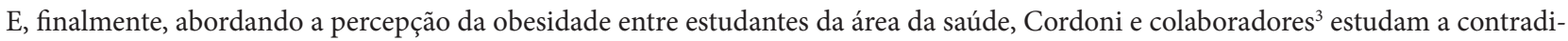
tória rejeição do individuo obeso pelos profissionais de saúde. Como um profissional “cuidador" pode, ao mesmo tempo, reconhecer um padrão de distúrbio e emitir juízo de valor? O quanto isto atrapalhará o diagnóstico e o tratamento quando ele tornar-se profissional? Será que isto acontece apenas com a obesidade, um fator visível e palpável?

De que modo a instituição pode corrigir a formação destes valores em nossos estudantes? Quem os forma? De que forma os pais, colegas e professores contribuem para formá-los? Aqui Cordoni et al. ofereceram um achado e a oportunidade de criarmos hipóteses, a grande chance de um estudo transversal. Parabéns aos autores. E aguardamos que a Academia se envolva após esta revelação.

Enfim, trata-se de uma combinação de estudos bem escolhidas pelo Editor e seu corpo cientifico de revisores. Afinal, além de interessantes por si mesmos, estes "papers" chamam atenção para a saúde de estudantes e suas instituições graças ao trabalho de professores e de alunos, também pesquisadores, que nos presenteiam com dúvidas e perguntas sobre onde podemos levar nossa formação técnica se não nos mantivermos atentos e sensíveis aos sinais mais simples de nosso dia a dia de educadores. Pois a qualidade de vida de estudantes universitários, como vários autores contemporâneos continuam mostrando, não é das melhores; embora seja objeto de pesquisa frequente.

\section{REFERÊNCIAS}

1. Alves TA, Malafaia G. Automedicação entre estudantes de uma instituição de ensino superior de Goiás. ABCS Health Sci. 2014;39(3):153-9. http://dx.doi.org/10.7322/abcshs.v39i3.649

2. Silva ML, Rego FS, Roque NF, Valenti VE. Use of psychoactive substances in students at a public university. ABCS Health Sci. 2014;39(3):160-6. http://dx.doi.org/10.7322/abcshs.v39i3.650

3. Cordoni JK, Rossaka VK, Reato LFN. Percepções dos estudantes da área de saúde sobre a obesidade. ABCS Health Sci. 2014;39(3):167-72. http://dx.doi.org/10.7322/abcshs.v39i3.651 